\title{
110 \\ Lichen floral studies on Artocarpus heterophyllus Lam. tree trunk in different eco -regions of Sri Lanka
}

\author{
M M K Karunarathne ${ }^{1}$, W J S K Weerakkody ${ }^{1}$ and D S A Wijesundara ${ }^{2}$ \\ ${ }^{1}$ Department of Plantation Management, Wayamba University of Sri Lanka, Sri Lanka \\ Royal Botanical Gardens, Peradeniya, Sri Lanka
}

\begin{abstract}
Information on lichen flora in Sri Lanka is scarce. Therefore a study was carried out to investigate lichens growing on a tree species common to all five eco regions (Montane, Wet, Intermediate, Arid and Dry zone) of Sri Lanka. The common tree species found in all regions was Artocarpus heterophyllus Lam. (jak). Lichen flora found on bark of jak trees between $1.5 \mathrm{~m}$ and $2 \mathrm{~m}$ above the ground level was studied. Six hundred and sixty three specimens from hundred and twenty trees were studied. Twenty five genera and thirteen families were found among them. Twenty genera were found to be crustose and five were folioses. No fruticose lichen was found in any region. Of all identified lichens $40 \%$ were belonged to the family Graphidaceae and it was the most frequently found lichen family in all regions and the second highest (17\%) was belonged to family Phyciaceae. The most frequently found genus was Graphis.
\end{abstract}

Heterodermia and Pertusaria were found only in montane zone while Leptogium was found only in lowland wet zone. Thelotrema, Ocellularia, Myriotrema and Chrysothrix were found only in Intermediate zone. Parmelia was restricted to wet zone while Dirinaria, Dimerella and Porina were restricted to dry zone. Differences in distribution of some of these lichens can be explained with rain fall, temperature and humidity.

Graphis and Opegrapha were found on jak tree trunks in all studied sites indicating that it has been well adapted to any environmental conditions in Sri Lanka.

\section{1}

\section{Diurnal avifaunal diversity, species richness and density along the Bolgoda canal in the Bellanwila- Attidiya sanctuary, western Sri Lanka}

\author{
U Dissanayaka and D Mahaulpatha \\ Department of Zoology, University of Sri Jayewardenepura, Sri Lanka.
}

Diurnal Avifaunal diversity, density and species richness were studied along the Bolgoda Canal in Bellanwila- Attidiya Sanctuary $\left(7^{\circ} 42^{\prime} \mathrm{N}, 79^{\circ} 49^{\prime} \mathrm{E}\right)$ of Western Sri Lanka from June 2005 to February 2006. Six lines transect (length $500 \mathrm{~m}$ ) totaling $3.00 \mathrm{~km}$ and positioned along the Bolgoda canal were travelled slowly on foot three times per month. The day was divided into three time periods as $0700-$ 1000 (morning), $1200-1500$ (noon) and $1500-1800$ (evening). Data were collected three times per month for each time period. All birds seen within one hundred meters on either side of each transect were recorded. Fifty-two bird species were recorded including globally endangered spotted billed pelican (Pelecanus philippensis) and four migratory species (Actitis hypoleucos,Burhinus odicnemus, Gelochelidon nilotica, Terpsiphone paradisi). Species diversity was significantly high in December 2005 and low in August 2005. (ANOVA, $F=17.00, p<0.05$ ) Species density was significantly high in September 2005 and low in June (ANOVA, $F=15.00, p>0.05$ ) Highest species richness was recorded in the morning session (Species richness $26.32 \pm 0.021$ ) and the lowest species richness was recorded in the noon session (Species richness 18.82 \pm 0.031 ). Species richness varied from $33.12 \pm 0.023$ in August $47.54 \pm 0.31$ in December 2005. Relative abundant indicated that House Crow (Corvus splendens) was the most abundant species while Lesser Whistling Duck (Dendrocyona iavanica) was the least abundance species. Present study revealed that although the study site is in close proximity to densely populated residential area; it still provides a vital habitat to large number of bird species and therefore warrants protection. 